удК 330.37 .07

\title{
ТРАНСФОРМАЦІЯ ОСВІТИ В СИСТЕМІ ІНФОРМАЦІЙНОГО СУСПІЛЬСТВА
}

\section{TRANSFORMATION OF EDUCATION IN THE SYSTEM OF THE INFORMATION SOCIETY}

\author{
Михайлова Єлизавета Вікторівна \\ кандидат фрілологічних наук, доцент, \\ Національний університет водного господарства та природокористування \\ ORCID: https://orcid.org/0000-0002-1539-1548
}

Mykhaylova Yelyzaveta

National University of Water and Environmental Engineering

\begin{abstract}
В статті досліджуються сфрера освіти та її фрунціонування у системі інформаційного суспільства, де основою $є$ продуктивні знання та якісна освіта, які визначають здатність до втілення інтелектуального капіталу в результати виробничої діяльності. Саме тому актуальним наразі стає процес вироблення та передачі знань, який не можливий без розвитку якісної освіти. Оскільки інформаційному суспільстві лише країна, що здатна конвертувати наукові знання в нові технології та товари, може забезпечити стійкі темпи економічного розвитку, трансформація сфери освіти стає пріоритетним завданням для держави. 3 огляду на те, що в інформаційному суспільстві знання стало товаром, досить прибутковим та з великим попитом, комерціалізація освіти може негативно вплинути на традиційну систему освіти. Саме тому актуальним завданням для країн, що перебувають на шляху до інформаційного суспільства, є ефективне поєднання традиційної системи освіти та сучасних інорормаційних технологій.
\end{abstract}

Ключові слова: інформаційне суспільство, економіка знань, освіта, економічна доцільність, людський капітал.

В статье исследуются сфера образования и ее функционирование в системе информационного общества, где основой являются продуктивные знания и качественное образование, которые определяют способность к воплощению интеллектуального капитала в результаты производственной деятельности. Именно поэтому актуальным сейчас становится процесс выработки и передачи знаний, который невозможен без развития качественного образования. Поскольку инорормационном обществе только страна, которая способна конвертировать научные знания в новые технологии и товары, может обеспечить устойчивые темпы экономического развития, трансформация сферы образования становится приоритетной задачей для государства. Учитывая то, что в инфрормационном обществе знания стало товаром, достаточно прибыльным и с большим спросом, коммерциализация образования может негативно повлиять на традиционную систему образования. Именно поэтому актуальной задачей для стран, находящихся на пути к информационному обществу, является эфффективное сочетание традиционной системы образования и современных информационных технологий.

Ключевые слова: информационное общество, экономика знаний, образование, экономическая целесообразность, человеческий капитал.

The education and its functioning in the information society system are viewed in this research. Taking into account that the the basis in this type of society is productive knowledge and quality education, the economic growth is determined by the ability to embody intellectual capital in the results of production activities. However, the problem of education and its functioning in the information society system, as well as its transformation to meet the demands of the information society remains insufficiently covered and still relevant. The main task of this research is to analyze the theoretical basis in order to form an effective model of the education system in the information society through a combination of traditional education and modern information technology. In such type of society, the knowledge economy is functioned, which is defined as a part of the economy that participates in the production and dissemination of knowledge. A knowledge-based economy in which knowledge plays a crucial role, and the production of knowledge becomes the driving force of society and a source of sustainable economic growth. Considering that in the information society only a country, which is capable to convert scientific knowledge into new technologies and goods, can ensure sustainable economic development, a human becomes the center of economic development and the same time a goal of development. The transition to the information society also involves the transformation of public administration, bearing in mind the new role of knowledge and information that become a source of power in 
society, as well as the development of new means of electronic communication and improving education. Because of this, the process of knowledge development and transfer is becoming relevant, which is not possible without the development of quality education. In the information society, where knowledge and information play a key role, the education system, in its traditional model, cannot ensure full implementation in the new type of society. That is why the urgent task for countries on the way to the information society is to effectively combine the traditional education system and modern information technologies.

Keywords: information society, knowledge economy, education, economic viability, human capital.

Постановка проблеми. В суспільстві, яке трансорормувалось до інфрормаційного, фрункціонує економіка знань, що визначається як частина економіки, яка бере участь у виробництві і поширенні знань. Тобто економіка, що базується на знаннях, в якій знання відіграють вирішальну роль, а виробництво знань стає рушійною силою розвитку суспільства і джерелом сталого економічного зростання. Оскільки основою інформаційного суспільства $€$ продуктивні знання та якісна освіта, які визначають здатність до втілення інтелектуального капіталу в результати виробничої діяльності, актуальним наразі стає процес вироблення та передачі знань, який не можливий без розвитку якісної освіти.

Аналіз останніх досліджень і публікацій. Деякі аспекти ффункціонування інфрормаційного суспільства досліджувались в роботах таких вітчизняних науковців як Ю. Атаманчук [2], В. Дрешпака [6], О. Кравчина [8], О. Овчарук [10]. Значний внесок в розвиток теорії інформаційного суспільства як модисрікації концепції постіндустріального суспільства внесли Д. Белл [3], Е. Гідденс [18], Е. Гелнер [17], П. Дракер [15], М. Порат [19], Ф. Фукуяма [19] та ін. Авторами концепції суспільства знання, яка з'явилася пізніше, ніж теорія постіндустріалізму та інфрормаційного суспільства стали Р. Райх [20], Т. Сакайя [13], та ін. М. Кастельс [12], який представив свою модель інсрормаційного суспільства у трилогії «Інформаційна епоха: економіка, суспільство та культура», розрізняє концепцію «інформаційне суспільство» (information society) та свою власну концепцію «інформаціональне суспільство» (informational society). Смислове навантаження у цьому понятті несе як іменник так і прикметник. Прикметник із суфріксом -al позначає процес, тобто процесах розгортання інформації, що символізує принципово новий характер відносин, іменник - підкреслює незмінність фрорм економічних відносин (прагнення до прибутку, принципи ринкової економіки та ін.) [14, с. 134]. Проте питання про сореру освіти та її фрункціонування у системі інсрормаційного суспільства, а також іiї транссрормацію для задоволення потреб інформаційного суспільства лишається недостатньо висвітленим та досі актуальним.

Виділення невирішених раніше частин загальної проблеми. 3 огляду на те, що в інформаційному суспільстві лише країна, що здатна конвертувати наукові знання в нові технології та товари, може забезпечити стійкі темпи економічного розвитку, людина стає у центр економічного розвитку як мета розвитку, як можливість реалізувати основні людські цінності й права. Саме тому системі інформаційного суспільства необхідно чітко визначати компоненти знань (освіта, науково-дослідна діяльність, комунікація та інформація), які $€$ основою для вибору видів діяльності та вимірювання внеску знань к економіку.

Формулювання цілей статті (постановка завдання). Основним завданням пропонованого дослідження $€$ аналіз теоретичного підґрунтя 3 метою фрормування ефрективної моделі системи освіти в інформаційному суспільстві через поєднання традиційної освіти та сучасних інорормаційних технологій.

Виклад основного матеріалу дослідження. Розвинуті країни, в яких суспільство вже трансорормувалось в інфрормаційне, характеризується перш за все тим, що більше $50 \%$ трудового населення країни зайнято виробництвом інформації та інфоормаційними послугами. Разом із тим у таких країнах розвинута система глобальної комунікації для забезпечення доступу до інформаційних ресурсів, крім того всіляко підтримується i заохочується усвідомлена необхідність підвищення рівня якості інформації та, загалом, рівня інфрормаційної культури.

У 60-70 роки XX ст. телекомунікаційні системи дали поштовх для розвитку освіти через радіо і телебачення, коли досвідчені викладачі, вчені, читали цікаві лекції із найрізноманітніших тем, пояснюючи наукових відкриттях [4, с. 91]. Разом із виникненням у 70-х рр. біхейвористських, а також гуманістичних та когнітивних підходів до навчання, із появою персональних комп'ютерів і відповідних програм почала розвиватися комп'ютерна освіта із використанням відеотехніки і засобів масової інорормації [9, с. 191]. 
Розвиток інтернету дозволив зробити процес навчання більш ефрективним завдяки створенню інтерактивного середовища із «зворотним зв'язком» та доступом до масивів різноманітних баз даних, включаючи великі наукові бібліотеки. Вже на початку 90-х була сорормована технологічна база інтерактивного, діалогового, середовища.

Оскільки, наразі суспільство перебуває у процесі становлення або ж переходу до інформаційного суспільства, відповідно управління освітою в таких умовах вимагає реалізацію певних заходів: проведення економічних та структурних ресрорм в освітньонауковій галузі з метою створення обстановки відкритості, есрективності, конкуренції та використання нововведень, що б доповнювалися заходами для адаптації на ринках праці, розвитку людських ресурсів і забезпечення соціальної згоди; раціональне використання наукових досягнень; розробка та застосування інформаційних мереж, що забезпечують швидкий та надійний доступ на ринок освітньо-наукових конкуренцій і відповідних нововведень до мережних технологій, їх обслуговування і застосування; розвиток людських ресурсів, здатних відповідати сучасним освітньо-управлінським вимогам, їх довічного навчання; активне використання IT в управлінні освітою, надання в режимі on-line послуг, необхідних для підвищення рівня державно-громадського управління [11, с. 30].

Останні стратегічні документи країн ЄС (Лісабонська декларація, Копенгагенська Декларація) передбачають, що фрормування інформаційної культури (e-Learning culture) в освітніх закладах має забезпечити застосування IKT у викладанні та навчанні через всі навчальні програми. Це стосується професійного розвитку та підготовки вчителів, підтримки розвитку шкільних бездротових мереж, технічної підтримки та вимог щодо оновлення техніки та програмного забезпечення, а також інформаційного змісту навчання. Мільйони учнів у всьому світі навчаються у дистанційному форматі, а із прискоренням глобалізації кількість учнів в мультимедійному просторі значно зросте. Засновниками глобального освітнього тренду вважаються британський «Відкритий університет» (OU, Open University) та іспанський «Національний університет дистанційної освіти» (UNED, Universitad Nasional a Distancia). Зараз ддним з найбільш відомих та впливових віртуальних університетів $€$ так званий «Проект Фантом». Це освітньо-індрормаційний консорціум, що складається з біблі- отеки Британського музею, бібліотеки Кембриджського університету, Лондонської школи економіки, шести канадських вищих закладів (Університет Святого Лаврентія, Відкритий університет Британської Колумбії, університети Атабаска, Ройял-Рудс, Брендон, Манітоба) та групи великих університетів США [1].

Проте Унісікація процесу освіти, консьюмеризація, гонитва за масштабами і масовий характер освітніх послуг істотно ускладнює виявлення індивідуальності студента і проведення відповідної індивідуальної роботи 3 ним. Тобто деперсоналізація освітнього процесу не може не позначитися на якості викладання. Завдяки непродуманим крокам у справі реформування освіти, переведення його в дистанційний формат неминуче пришвидшиться процес освітньо-педагогічної інфляції і в подальшому - планетарне зниження рівня освіти в особливості в вищих навчальних закладах [4].

Сьогодні, з економічної точки зору, вартість аудиторних занять зростає. Тому видається недоцільним витрачати ці години на пояснення матеріалу, який можна освоїти самостійно із доступом до курсу через інтернет. А в аудиторіях $\epsilon$ сенс будувати заняття у фрормі діалогу із запитаннями, де якраз і реалізується консультативна функція. Варто зазначити, що таку форму навчання обирають й студенти, які самостійно оплачують навчання. Таким чином, педагог в інфрормаційному суспільстві виконує відразу дві фрункції: а) створення освітніх середовищ; б) консультативна.

Крім того, в останні роки в закладах вищої освіти була тенденція до скорочення аудиторних годин та спроб частково перейти на дистанційну освіту.

Реальність 2020 року внесла свої корективи. Із розповсюдження епідемії COVID-19 та запровадження карантинних обмежень освітні заклади були змушені перейти на систему дистанційної освіти. В перші місяці карантину, можливо навіть протягом першого семестру, більшість ЗВО нашої країни не були готові до такого вимушеного переходу. Застаріла методика викладання, відсутність технічних можливостей як у студентів так і у педагогів та небажання педагогів змінювати свою роль у системі освіти стали призвели до того, що дистанційна освіта була примітивною, не індивідуальною та безособовою.

Перехід суспільства від промислового до інсрормаційного i, зокрема, модернізація освітньої сорери реалізовується у державних програмах інсрорматизації, які охоплюють про- 
цеси фрормування передумов (організаційних, науково-технічних, економічних, фрінансових, гуманітарних, правових) розвитку інформатизації, розвиток сучасних інфоормаційних технологій у всіх сорерах суспільного життя, фрормування системи національних інформаційних ресурсів, створення системи інсоормаційноаналітичної підтримки діяльності органів державної, підвищення ефрективності вітчизняного виробництва на основі широкого використання інформаційних технологій та формування ринку інфрормаційних продуктів та послуг [10].

Основними напрямками реформування сорери освіти в частині упровадження інфрормаційних технологій є:

- створення банків і баз даних з віддаленим доступом по окремим галузям науки і техніки;

- розвиток системи електронних публікацій і електронних періодичних видань наукового профрілю;

- створення електронних науково-технічних бібліотек з віддаленим доступом, систем електронної публікації в Internet і систем електронної доставки документів;

- створення www серверів наукових шкіл;

- створення загальнодоступних архівів програмного забезпечення технічної документації і патентів;

- створення баз знань і експертних систем з віддаленим доступом;

- забезпечення можливості використання комп'ютерних центрів для реалізації віддалених нарахувань і віддаленого доступу до потужних САПР;

- створення інтелектуальних пошукових систем, що забезпечують можливість глибокого і адаптивного пошуку наукової інфрормації;

- створення віртуальних виставок наукових і технічних досягнень вищої школи;

- створення механізму проведення національних і міжнародних наукових відеоконореренцій і семінарів;

- створення віртуальних наукових лабораторій [7, с. 35].

До особливостей процесу освіти в умовах інфрормаційного суспільства можна віднести наступні явища, які, в свою чергу, варто умовно поділити на «позитивні» та «негативні».

До позитивних ми можемо віднести наступні явища .

- унікальні можливості доступу до інфрормації. Можливість її миттєвого отримання на будь-якому віддаленому сервері з будь-якої місця без істотних грошових і часових витрат.

- Інтерактивний характер взаємодії 3 інформацією. Можливість побудови індивіду- ального «сценарію» знаходження в інсрормаційному просторі.

- Різноманітність «форматів» подання інфрормації: гіпертекст, відео, звук та інші фрорми мультимедійних способів створення «віртуальної реальності». Можливість зробити процес освіти захоплюючим та цікавим.

- «Відкритість» інфрормаційного середовища для індивідуальної творчості. Можливість створювати щось і відразу ж робити надбанням усіх користувачів інтернету. Проте в той самий час ця можливість породжує й негативний аспект, так як на суд користувачів можна винести абсолютно будь-який продукт незалежно від його якості.

До негативних ми можемо віднести наступні явища:

- Психологічна залежність користувачів мережі («інтернет-аддикцію»), що супроводжується в тому числі ослабленням соціальних зв'язків та іншими наслідками переходу у віртуальну реальність.

-Зміна відносин в системі «учитель-учень», в якій найбільш цінним $€$ процес традиційної усної передачі знань. 3 іншого боку, таку зміну можна охарактеризувати як зняття внутрішньої опозиції «учитель - учень». Сьогодні все частіше говорять про зміщення ролі вчителя в сторону «консультанта». Спілкування у парі «учитель - учень», безумовно, залишиться в соері освіти, а особливо коли мова йде про передачу культурної і духовної традиції. Але і роль вчителя-консультанта із розвитком інформаційних освітніхсистем виправдана з усіх точок зору і тому абсолютно неминуча.

- Використання інфрормації через Інтернет без найменшої творчої «переробки» призводить до навчання «мистецтва компіляції» замість «мистецтва вироблення креативу». Тобто зникає здатність творчого засвоєння та індивідуальної переробки інформації [5, с. 123].

Висновки. Інформаційне суспільство - це суспільство знань, в якому панує економіка, де знання відіграють вирішальну роль, а їх виробництво стає джерелом розвитку. Основними рисами такого суспільства є: велика частка у ВВП сорер пов'язаних із пов'язаних 3 виробництвом знань, зі створенням та впровадженням технологій та інших продуктів інтелектуальної діяльності, із наданням послуг у сорерах інфрорматизації, освіти, зв'язку, а також у сорері пошуку, передачі, отримання та поширення інформації; прискорення науковотехнічного прогресу та перетворення наукових знань в реальний фактор виробництва, підвищення якості життя людини і суспіль- 
ства; участь значної частини працездатного населення у виробничій діяльності, пов'язаної зі створенням та використанням інорормаційних технологій, інформації і знань; суттєве розширення можливостей громадян з пошуку, накопичення, передачі, виробництва та розповсюдження інформації і знань; глобалізація економічної, політичної та духовної сорер життя суспільства.

Перехід до інформаційного суспільства передбачає також трансорормацію державного управління із урахуванням нової ролі знань та інфрормації, які стають джерелом влади у суспільстві, а також розвиток нових засобів електронної комунікації та підвищення рівня освіти. Інорорматизація всіх управлінських процесів є ключовою особливістю нової моделі державного управління.

В інфрормаційному суспільстві, де знання та інорормація відіграють ключову роль, система освіти в державі виходить не передній план. Проте система освіти, у їі традиційній моделі, не може забезпечити повноцінну реалізацію в новому типі суспільства. В умовах інфрормаційного суспільства освіта має певні особливості, які можна охарактеризувати як позитивні та негативні. Унікальні можливості доступу до інорормації, інтерактивний характер взаємодії з інформацією; різноманітність «форматів» подання інфрормації; «відкритість» інфрормаційного середовища для індивідуальної творчості дозволяють перетворити навчання на безперервний, творчий процес, що є доступним із будь-якої точки у будь-який час. Проте, негативними проявами можна вважати психологічну залежність користувачів мережі, зміна відносин «учитель-учень» та використання інорормації з інтернету без жодної творчої обробки.

Сьогодні мільйони учнів у всьому світі навчаються у дистанційному форматі, а із прискоренням глобалізації кількість учнів в мультимедійному просторі значно зросте.
Наразі така тенденція підтвердилась, коли через пандемію COVID-19 система освіти змушена була перейти на дистанційні форми навчання. Проте, масовий характер освітніх послуг істотно ускладнює виявлення індивідуальності студента і проведення відповідної індивідуальної роботи з ним, що в свою чергу не може не позначитися на якості викладання.

Модернізація освітньої сфрери в інформаційному суспільстві реалізовується у державних програмах інформатизації, які охоплюють процеси фрормування передумов (організаційних, науково-технічних, економічних, фрінансових, гуманітарних, правових) розвитку інфрорматизації, розвиток сучасних інформаційних технологій у всіх сфрерах суспільного життя, фрормування системи національних інфрормаційних ресурсів, створення системи інфрормаційноаналітичної підтримки діяльності органів державної, підвищення ефективності вітчизняного виробництва на основі широкого використання інформаційних технологій та формування ринку інформаційних продуктів та послуг.

Оскільки в інфрормаційному суспільстві знання стало товаром, досить прибутковим та 3 великим попитом, комерціалізація освіти може негативно вплинути на традиційну систему освіти. Через те, що вища освіта розглядається як товар, який можна продати або ж придбати, вона виходить рівень світового ринку, в результаті чого імпорт і експорт освітніх послуг може стати предметом складних процедур цієї організації і юридичного нормування її рішеннями.

Саме тому актуальним завданням для країн, що перебувають на шляху до інорормаційного суспільства, $€$ ефективне поєднання традиційної системи освіти та сучасних інфрормаційних технологій. Зокрема, для України однією $з$ найбільш важливих завдань сьогодні $€$ швидка і ефективна модернізація освітньої системи з огляду на прискорення європейської інтеграції в галузі вищої освіти

\section{СПИСОК ВИКОРИСТАНИХ ДЖЕРЕЛ:}

1. Алієв Х.М. Зарубіжний досвід упровадження дистанційного навчання в університетах. Наукові записки Бердянського державного педагогічного університету. Сер. : Педагогічні науки. 2017. Вип. 3. С. 11-17.

2. Атаманчук Ю.М. Державне управління освітою в умовах інформаційного суспільства. Вісник Черкаського університету. Серія Педагогічні науки. 2009. № 157. С. 9-13.

3. Белл Д. Грядущее постиндустриальное общество. Опыт социального прогнозирования / пер. с англ. Изд. 2-ое, испр. и доп. Москва : Academia, 2004. 788 с.

4. Буряк В.В. Образование в информационном обществе. Філософія освіти. 2006. 1(3). С. 89-100. URL: https://cyberleninka.ru/article/n/obrazovanie-v-informatsionnom-obschestve-1/viewer (датазвернення 10.08.2021).

5. Васильев В., Сухорукова М. Информационное общество и образование. Высшее образование в России. 2004. № 7. С. 122-129. 
6. Дрешпак В. Становлення державної інформаційної політики України: зміст і хронологічні межі основних періодів. Державне управління та місцеве самоврядування. 2013. Вип. 4. С. 3-13.

7. Клейнер Г. Микроэкономика знаний и мифы современной теории. Высшее образование в России. 2006. № 9. С. 32-37.

8. Кравчина О.Є. Використання комп'ютерно орієнтованого навчального середовища для розвитку підприємницької компетентності учнів (європейський досвід) . Науковий вісник Ужгородського університету. Серія : Педагогіка. Соціальна робота. 2020. Вип. 1. С. 174-179. URL: http://nbuv.gov.ua/UJRN/Nvuuped_2020_1_36 (дата звернення: 10.08.2021).

9. Лоу Л. Образование и развитие человеческих ресурсов: движущая сила следующего столетия. Постиндустриальный мир и Россия. Москва : Эдиториал УРСС, 2001. С. 179-196.

10. Овчарук О.В. Проблеми поширення освітніх інновацій та інноваційних освітніх проектів в Україні . Постметодика. 2013. № 2. С. 2-5. URL: http://nbuv.gov.ua/UJRN/Postmetodyka_2013_2_3 (дата звернення: 10.08.2021).

11. Рябенко Є.М. Соціально-фрілософські засади державного управління вищою освітою в умовах інформаційного суспільства . Гуманітарний вісник Запорізької державної інженерної академії. 2013. Вип. 52. С. $25-32$.

12. Кастельс М. Информационная эпоха: экономика, общество и культура / пер. с англ. под науч. ред. О.И. Шкаратана. Москва : ГУ ВШЭ, 2000. 608 с

13. Сакайя Т. Стоимость, создаваемая знаниями, или история будущего / под ред. В.Л. Иноземцева. Москва : Academia, 1999. 640 c.

14. Уэбстер Ф. Теория информационного общества / пер. с англ. М.В. Арапова, Н.В. Малыхиной; под ред. Е.Л. Варталовой. Москва : Аспект Пресс, 2004. 400 с.

15. Drucker P. The Future of Industrial Man: A Conservative Approach. New York: The John Day Company, 1942. 298 p. 16. Fukuyama F. Identity: The Demand for Dignity and the Politics of Resentment. Farrar, Straus \& Giroux, 2018.240 p. 17. Gellner E. Contemporary Thought and Politics. London : Routledge, 1974. 222 p.

18. Giddens A. The Constitution of Society. Outline of the Theory of Structuration. Berkeley and Los Angeles : University of California Press, 1998. 444 p.

19. Porat M. The Information Economy: User's Guide to the Complete Database (on Magnetic Tape). Washington : Office of Telecommunications, 1977. 63 p.

20. Reich R. The Work of Nations: Preparing Ourselves for 21st Century Capitalism. New York : Vintage Books, 1992.

\section{REFERENCES:}

1. Aliiev Kh.M. (2017) Zarubizhnyi dosvid uprovadzhennia dystantsiinoho navchannia v universytetakh [Foreign experience of distance learning in universities]. Naukovi zapysky Berdianskoho derzhavnoho pedahohichnoho universytetu - Scientific notes of Berdyansk State Pedagogical University, 3, 11-17. (in Ukrainian)

2. Atamanchuk Yu.M. (2009) Derzhavne upravlinnia osvitoiu v umovakh informatsiinoho suspilstva [Public administration of education in the information society]. Visnyk Cherkaskoho universytetu. Seriia Pedahohichni nauky - Bulletin of Cherkasy University. Pedagogical Sciences Series, no. 157, 9-13. (in Ukrainian)

3. Bell D. (2004) Grjadushhee postindustrial'noe obshhestvo. Opyt social'nogo prognozirovanija [The coming post-industrial society. Experience of social forecasting]. In English trans. Moscow: Academia, 788. (in Russian)

4. Buryak V.V. (2006) Obrazovanie $v$ informatsionnom obshchestve [Education in the information society]. Filosofiya osviti - Philosophy of education, 1(3), 89-100. Retrieved from: https://cyberleninka.ru/article/n/obrazovanie-v-informatsionnom-obschestve-1/viewer (in Russian)

5. Vasil'ev V., Sukhorukova M. (2004) Informatsionnoe obshchestvo i obrazovanie [Information society and education]. Vysshee obrazovanie $v$ Rossii - Higher education in Russia, no. 7, 122-129. (in Russian)

6. Dreshpak V. (2013) Stanovlennia derzhavnoi informatsiinoi polityky Ukrainy: zmist i khronolohichni mezhi osnovnykh periodiv [Formation of the state information policy of Ukraine: content and chronological boundaries of the main periods]. Derzhavne upravlinnia ta mistseve samovriaduvannia - Public administration and local selfgovernment, 4, 3-13. (in Ukrainian)

7. Kleyner G. (2006) Mikroekonomika znaniy i mify sovremennoy teorii [Microeconomics of knowledge and myths of modern theory]. Vysshee obrazovanie $v$ Rossii - Higher education in Russia, 9, 32-37. (in Russian)

8. Kravchyna O.Ye. (2010) Vykorystannia komp'iuterno oriientovanoho navchalnoho seredovyshcha dlia rozvytku pidpryiemnytskoi kompetentnosti uchniv (ievropeiskyi dosvid) [The use of computer-based learning environment for the development of entrepreneurial competence of students (European experience)]. Naukovyi visnyk Uzhhorodskoho universytetu. Seriia: Pedahohika. Sotsialna robota - Scientific Bulletin of Uzhhorod University. Series: Pedagogy. Social work, 1, 174-179. Retrieved from: http://nbuv.gov.ua/UJRN/Nvuuped_2020_1_36 (in Ukrainian) 
9. Lou L. (2001) Obrazovanie i razvitie chelovecheskikh resursov: dvizhushchaya sila sleduyushchego stoletiya [Education and development of human resources: the driving force of the next century.]. Postindustrial'nyy mir $i$ Rossiya - Post-industrial world and Russia. Moscow: Editorial URSS, 179-196. (in Russian)

10. Ovcharuk O.V. (2013) Problemy poshyrennia osvitnikh innovatsii ta innovatsiinykh osvitnikh proektiv v Ukraini [Problems of dissemination of educational innovations and innovative educational projects in Ukraine]. Postmetodyka - Postmethodology, 2, 2-5. Retrieved from: http://nbuv.gov.ua/UJRN/Postmetodyka_2013_2_3 (in Ukrainian)

11. Riabenko Ye.M. (2013) Sotsialno-filosofski zasady derzhavnoho upravlinnia vyshchoiu osvitoiu $v$ umovakh informatsiinoho suspilstva [Socio-philosophical principles of public administration of higher education in the information society]. Humanitarnyi visnyk Zaporizkoi derzhavnoi inzhenernoi akademii - Humanitarian Bulletin of the Zaporizhia State Engineering Academy, 52, 25-32. (in Ukrainian)

12. Kastel's M. (2000) Informatsionnaya epokha: ekonomika, obshchestvo i kul'tura [Information age: economy, society and culture] / In O.I. Shkaratana (eds.). Moscow: GU VShE, 608. (in Russian)

13. Sakayya T. (1999) Stoimost', sozdavaemaya znaniyami, ili istoriya budushchego [The value created by knowledge, or the history of the future] / In V.L. Inozemtseva (eds.). Moscow: Asademia, 640. (in Russian)

14. Uebster F. (2004). Teoriya informatsionnogo obshchestva [Theory of the information society] / In M.V. Arapova, N.V. MalykhinoI (trans.), in E.L. Vartalovoľ (eds.). Moscow: Aspekt Press, 400. (in Russian)

15. Drucker P. (1942) The Future of Industrial Man: A Conservative Approach. New York: The John Day Company, 298. (in English)

16. Fukuyama F. (2018) Identity: The Demand for Dignity and the Politics of Resentment. Farrar, Straus \& Giroux, 240. (in English)

17. Gellner E. (1974) Contemporary Thought and Politics. London: Routledge, 222. (in English)

18. Giddens A. (1998) The Constitution of Society. Outline of the Theory of Structuration. Berkeley and Los Angeles: University of California Press, 444. (in English)

19. Porat M. (1977) The Information Economy: User's Guide to the Complete Database (on Magnetic Tape). Washington: Office of Telecommunications, 63. (in English)

20. Reich R. (1992) The Work of Nations: Preparing Ourselves for 21st Century Capitalism. New York: Vintage Books. (in English) 